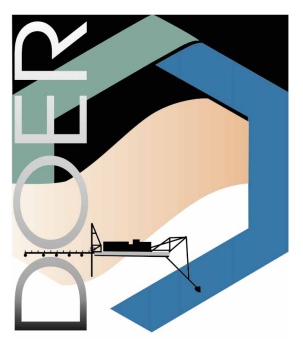

\title{
Economic Impacts of Environmental Windows Associated with Dredging Operations
}

PURPOSE: This technical note describes potential economic impacts that result from compliance with requests for environmental windows (i.e., temporal constraints) on dredging operations. The primary purpose of this effort was not to quantify the exact total cost attributable to environmental windows throughout the U.S. Army Corps of Engineers (USACE) dredging program, but rather to estimate incremental costs of windows compliance across a spectrum of dredging project scenarios. The information contained herein, when examined in tandem with characterizations of the frequencies of windows associated with Federal dredging projects and the technical issues used to justify requests for specific environmental windows (Reine, Dickerson, and Clarke 1998), is intended to support decisions regarding prioritization of directions of future research.

BACKGROUND: Environmental windows are temporal constraints placed upon the conduct of dredging or dredged material disposal operations in order to protect biological resources or their habitats from potentially detrimental effects. Environmental windows are based on the simple logic that potential conflicts or detrimental effects can be avoided by preventing dredging or disposal during times when biological resources are present or most sensitive to disturbance. The environmental effects of turbidity, suspended sediments, sedimentation, and hydraulic entrainment on aquatic resources are some of the primary concerns leading to environmental windows for dredging projects in coastal, estuarine, or freshwater waterways (Reine, Dickerson, and Clarke 1998).

Approximately 80 percent of all Civil Works Operations and Maintenance (O\&M) dredging conducted by the USACE is subject to some form of environmental window. In many cases, however, compliance with requests for windows creates unavoidable contracting complications, scheduling delays, reduced dredge plant and equipment options, reduced flexibility for mobilization/ demobilization, limited contingencies for unanticipated repairs and weather delays, and increased safety hazards. These factors can contribute to added costs. Since 1992, when comparative data began to be collected, the total cost of USACE-sponsored dredging has increased significantly, without a commensurate increase in the total volume of material dredged (Pointon 1996). A perception exists among dredging project managers that costs calculated on a per cubic yard basis for individual projects have risen disproportionately over time, even when inflation and industrydriven cost factors are taken into account. One widely held explanation is that costs attributable to compliance with environmental windows are directly linked to the observed trend of increasing total dredging costs. However, an indepth analysis of the economics of dredging has never been performed such that relationships between a host of cost factors, including environmental considerations, can be substantiated and quantified.

Dredging project managers, while cognizant of the need to protect biological resources, are also mandated by Congress to conduct authorized dredging operations in as cost-effective a manner as possible. When the justification for an environmental window appears to be technically sound and the requesting agencies have clearly articulated their underlying concerns, compliance with a 
window seldom becomes controversial, even if increased costs occur. However, many inconsistencies exist in the application of environmental windows and in the technical bases used to justify these restrictions (Profiles Research and Consulting Groups 1980, LaSalle et al. 1991).

Environmental windows which are inconsistent or over-restrictive are likely to continue to be recommended until sufficient technical data become available upon which to make a rigorous technical evaluation of the actual need for a given window. Ensuring that valuable natural resources receive adequate protection and preventing unwarranted delays and costs in dredging and disposal operations require a more complete understanding of basic technical issues. Because the technical issues relevant to environmental windows are diverse and complex, prudent investment of research funding requires an economic analysis of associated costs from complying with these restrictions. Optimal return on finite research funds can only be achieved through focused effort on technically resolvable issues associated with windows having the greatest economic impact on the national dredging program.

METHODS: There is little precedence in estimating costs attributable to compliance with environmentally driven constraints on dredging projects. Potential costs arising from regulatory (Boerger and Cheney 1976) and nonwindows related factors (Cable and Pearson 1976) have been alluded to, but no methodology to quantify such costs has been identified. To our knowledge, no prior studies of the economics of environmental windows exist. Thus estimating such costs presents a significant challenge. USACE Districts were surveyed (Figure 1) for information related to restrictions on various dredging project types (e.g., maintenance versus new work material; hopper, bucket, or hydraulic dredge; cubic yardage; coarse versus fine grained material; etc.). Respondents were asked for specific information on: (a) the resource being protected, (b) environmental alteration of concern or potential detrimental effects forming the underlying reason for the restriction, (c) start/end dates of requested windows, (d) project type, specific activities of concern, and dredged material volume, (e) dredging cycle of the restricted project, and (f) resource agency recommending the window. Details of the survey can be found in Reine, Dickerson, and Clarke (1998).

Data describing the temporal constraints and economic effects of existing environmental windows on dredging projects were assimilated from several sources including: (a) survey responses, (b) archived USACE District dredging project files, (c) dredging scenario project costs generated using the USACE Cost Engineering Dredge Estimating Program (CEDEP) (Fletcher and Fore 1996), and (d) the USACE Contract Dredging Program Database (Pankow 1997). The survey responses and archived project files provided cost factor information characterizing dredging projects in specific Districts and regions. This information was then used to formulate 38 hypothetical dredging project scenarios covering the most common conditions encountered. Next, the CEDEP was used to estimate costs per cubic yard of dredged material for each of the 38 hypothetical dredging scenarios with predetermined periods, or "windows," in which to complete the required dredging. Thus, the effect of windows of different durations on a given project could be simulated by setting alternative values for start/end dates (total time allowed) as well as dredge plant efficiencies (note: efficiency as defined by the CEDEP refers to time in operation rather than production rates or percent solids). In brief, the CEDEP integrates a number of cost factor variables that are either project dependent (e.g., time allowed to complete dredging, dredge plant type, dredge plant size/production, mode of disposal, distance to disposal site, average pumping distance, 


\begin{tabular}{|c|c|c|c|c|c|c|c|}
\hline \multicolumn{8}{|c|}{ USACE Districts and Divisions } \\
\hline \multicolumn{2}{|c|}{$\begin{array}{l}\text { POD Pacific Ocean } \\
\text { Division }\end{array}$} & \multicolumn{2}{|c|}{$\begin{array}{l}\text { NWD Northwestern } \\
\text { Division }\end{array}$} & \multicolumn{2}{|c|}{$\begin{array}{l}\text { LRD Great Lakes and } \\
\text { Ohio River Division }\end{array}$} & \multicolumn{2}{|c|}{$\begin{array}{l}\text { NAD North Atlantic } \\
\text { Division }\end{array}$} \\
\hline $\begin{array}{l}\mathrm{POA} \\
\mathrm{POH}\end{array}$ & $\begin{array}{l}\text { Alaska District } \\
\text { Honolulu District }\end{array}$ & $\begin{array}{l}\text { NWK } \\
\text { NWO } \\
\text { NWP } \\
\text { NWS } \\
\text { NWW }\end{array}$ & $\begin{array}{l}\text { Kansas City District } \\
\text { Omaha District } \\
\text { Portland District } \\
\text { Seattle District } \\
\text { Walla Walla District }\end{array}$ & $\begin{array}{l}\text { LRB } \\
\text { LRC } \\
\text { LRE } \\
\text { LRH } \\
\text { LRL } \\
\text { LRN } \\
\text { LRP }\end{array}$ & $\begin{array}{l}\text { Buffalo District* } \\
\text { Chicago District } \\
\text { Detroit District } \\
\text { Huntington District } \\
\text { Louisville District } \\
\text { Nashville District } \\
\text { Pittsburgh District } \\
\end{array}$ & $\begin{array}{l}\text { NAB } \\
\text { NAE } \\
\text { NAN } \\
\text { NAO } \\
\text { NAP }\end{array}$ & $\begin{array}{l}\text { Baltimore District } \\
\text { New England District } \\
\text { New York District } \\
\text { Norfolk District } \\
\text { Philadelphia District }\end{array}$ \\
\hline \multicolumn{2}{|c|}{$\begin{array}{c}\text { SPD South Pacific } \\
\text { Division }\end{array}$} & \multicolumn{2}{|c|}{$\begin{array}{c}\text { SWD Southwestern } \\
\text { Division }\end{array}$} & \multicolumn{2}{|c|}{$\begin{array}{c}\text { MVD Mississippi Valley } \\
\text { Division }\end{array}$} & \multicolumn{2}{|c|}{$\begin{array}{c}\text { SAD South Atlantic } \\
\text { Division }\end{array}$} \\
\hline $\begin{array}{l}\text { SPA } \\
\text { SPL } \\
\text { SPK } \\
\text { SPN }\end{array}$ & $\begin{array}{l}\text { Albuquerque District } \\
\text { Los Angeles District } \\
\text { Sacramento District } \\
\text { San Francisco District }\end{array}$ & $\begin{array}{l}\text { SWF } \\
\text { SWG } \\
\text { SWL } \\
\text { SWT }\end{array}$ & $\begin{array}{l}\text { Fort Worth District } \\
\text { Galveston District } \\
\text { Little Rock District } \\
\text { Tulsa District }\end{array}$ & $\begin{array}{l}\text { MVM } \\
\text { MVN } \\
\text { MVR } \\
\text { MVS } \\
\text { MVP } \\
\text { MVK }\end{array}$ & $\begin{array}{l}\text { Memphis District } \\
\text { New Orleans District } \\
\text { Rock Island District } \\
\text { St. Louis District } \\
\text { St. Paul District } \\
\text { Vicksburg District }\end{array}$ & $\begin{array}{l}\text { SAC } \\
\text { SAJ } \\
\text { SAM } \\
\text { SAS } \\
\text { SAW }\end{array}$ & $\begin{array}{l}\text { Charleston District } \\
\text { Jacksonville District } \\
\text { Mobile District } \\
\text { Savannah District } \\
\text { Wilmington District }\end{array}$ \\
\hline
\end{tabular}

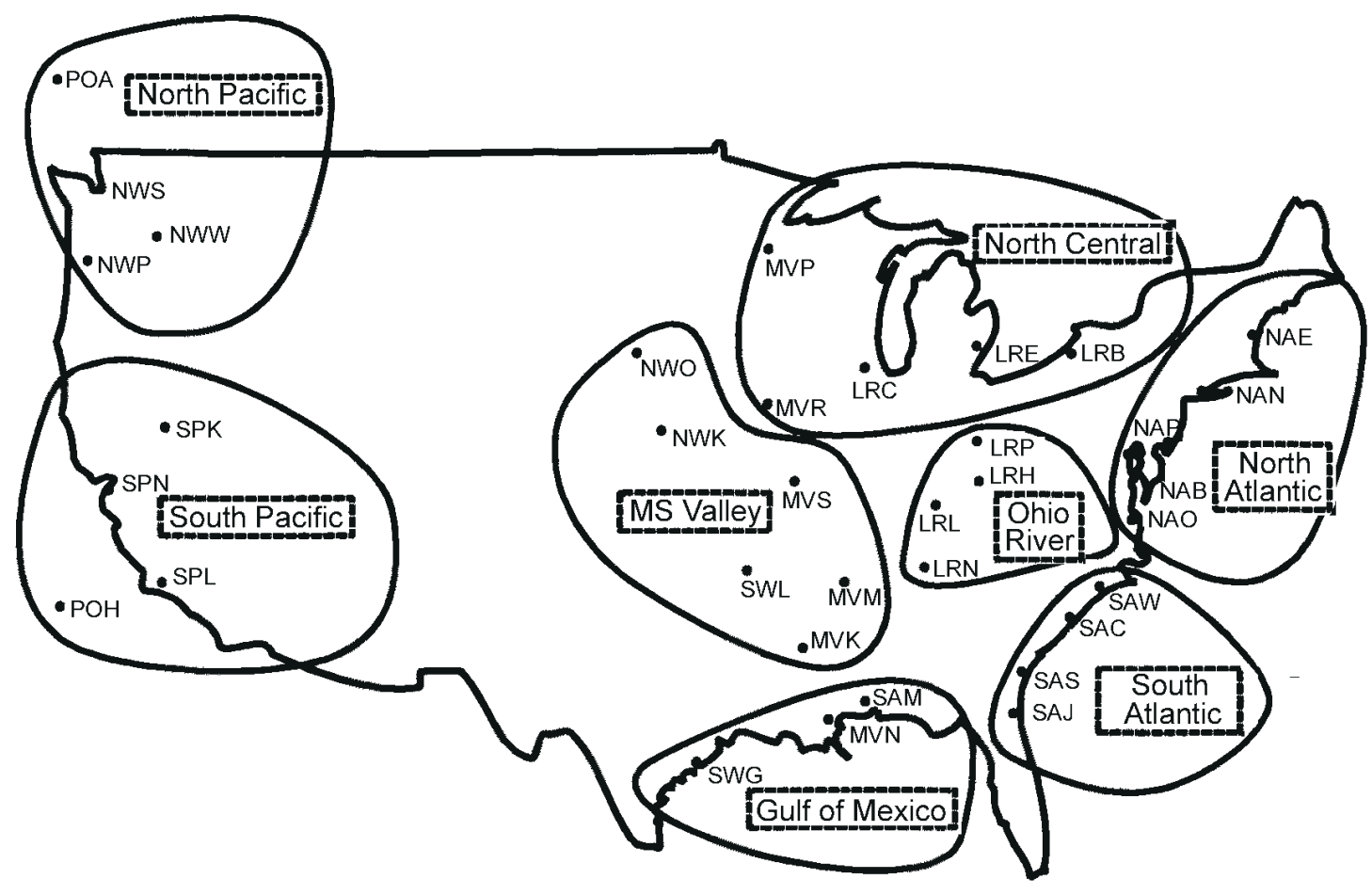

Figure 1. USACE Districts by Division and geographical regions 
dredged material characteristics, and total volume to be dredged) or geographic region dependent (e.g., prevailing labor/wage rates, fuel costs, equipment mobility and logistics, anticipated weather delays, personnel requirements, and insurance costs) to calculate an estimate of total project cost for use in the contract bidding and award process.

Estimates of annual costs and cubic yards of dredged material encompassing discrete categories of dredging projects with environmental windows were calculated using the Contract Dredging Program Database (Pankow 1997). Although this database treats only one component (contracts to nongovernment dredge plants) of the entire USACE dredging program, it represents the most accurate, comprehensive, and accessible source of data characterizing relevant projects. Further cost analyses of other aspects of the dredging program (e.g., government dredge plants, non-Federal projects) would demonstrate additional economic effects, but these would be extremely difficult to quantify.

Results of the survey responses and economic analyses were organized and evaluated by: (a) resource of concern or technical issue, (b) Districts and Divisions, (c) geographic region, (d) project type, and (e) dredged material volume. Evaluation of issues by geographic region is important because of the logistics involved with the availability and scheduling of dredge plants (Figure 1). Categorized data were then ranked to help prioritize the technical issues and concerns which need to be addressed. Reine, Dickerson, and Clarke (1998) provide detailed summaries of these technical issues and concerns, whereas this note focuses solely on the economic impacts of environmental windows.

\section{RESULTS:}

Survey responses. Approximately 64 percent of USACE personnel provided with survey questionnaires responded (86 responses representing 37 Districts). Four Districts (Albuquerque, NM; Fort Worth, TX; Tulsa, OK; and Vicksburg, MS) reported no environmental windows, reflecting their lack of or limited dredging activities, while some Districts indicated extensive restrictions, usually due to concerns over commercially valuable resources, threatened and endangered species, or protected habitats. Five Districts (Galveston, TX; St. Louis and Kansas City, MO; Omaha, NE; and Memphis, TN), which previously reported no environmental issues in Sanders and Killgore (1989), reported dredging issues or concerns in this survey.

Frequencies and distributions of windows. In order to evaluate potential economic costs attributable to windows compliance, it is important to consider the type, frequency, and magnitude (volume) of the dredging project. The mean number of Federal dredging contracts by dredge plant type (1987-1996) was calculated using both the survey responses and the Contract Dredging Program Database (Pankow 1997) (Figure 2). Hydraulic pipeline operations (63 percent) comprised the majority of Federal dredging contracts, followed by mechanical dredge (15 percent) and hopper dredge (14 percent) projects (Pointon 1996; Pankow 1997). Projects moving large volumes of dredged material primarily utilize pipeline and hopper dredges; whereas, mechanical (bucket or clamshell) dredges are most often used with smaller volume projects (Figure 3). Although fewer dredging projects are done using hopper and mechanical dredges than with pipeline dredges, a higher proportion of restrictions were identified for hopper (83.2 percent) and mechanical (84.5 percent) dredging operations as compared to pipeline (66.7 percent) projects (Figure 2). Maintenance 


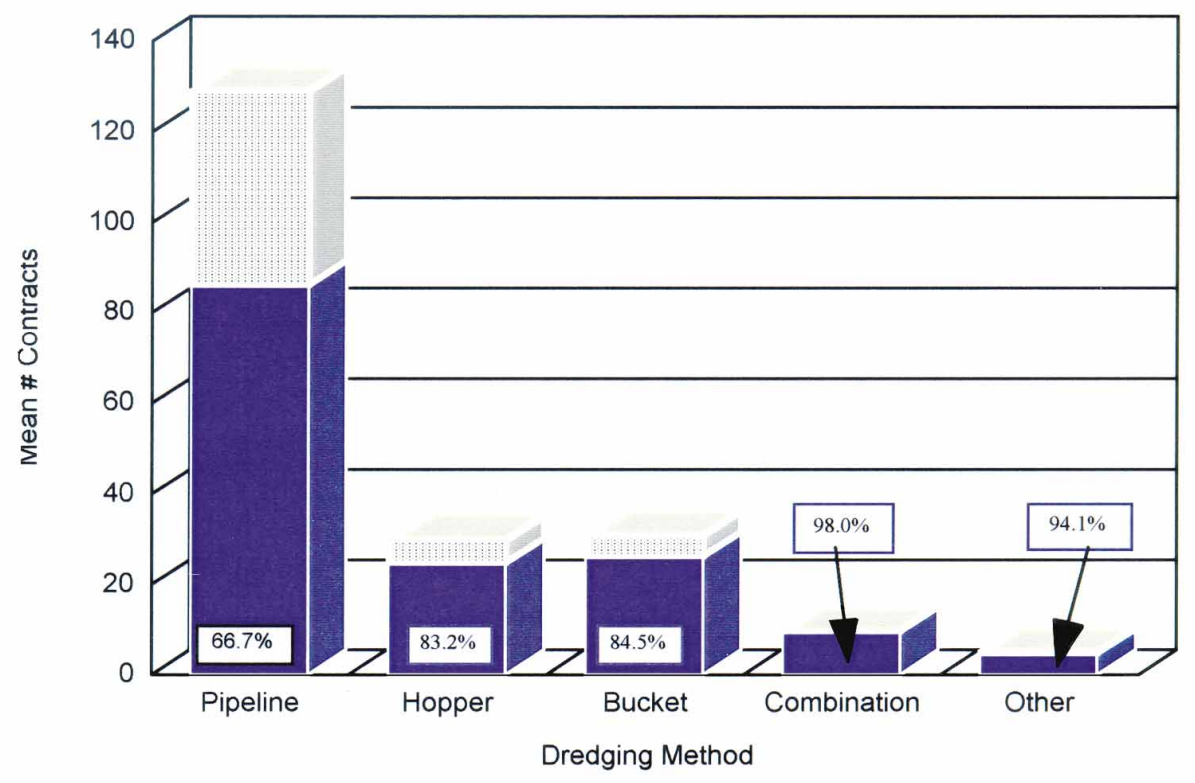

With Restrictions

W/O Restrictions

Figure 2. Estimated annual distribution of environmental windows by dredging method (Federal dredging contracts only) during 1987-1996

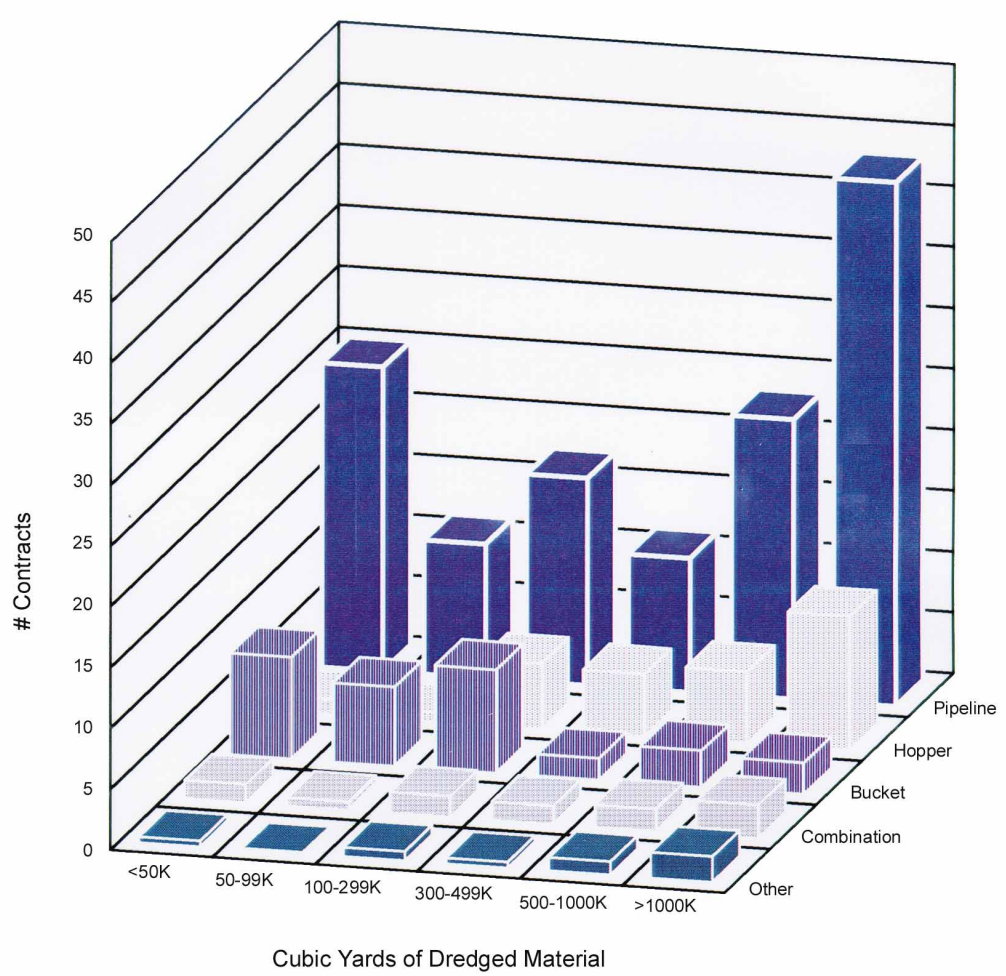

Figure 3. Mean annual number of Federal dredging contracts by dredging category (1987-1996) (based on Pankow 1997) 
dredging and disposal operations, primarily conducted by contracted (industry) dredges, were commonly affected by environmental windows (Pointon 1996).

The geographic distribution of contract dredging activity and the associated proportion of projects with environmental windows are shown in Figure 4. Great variation in the incidence of windows can be seen throughout the USACE dredging program, reflecting geographical differences in environmental concerns, regional differences in resource management agency perceptions of the need for windows, regional differences in types of dredging activities, and perhaps uneven representation of responses within the survey. The North Atlantic region had the highest average annual number of dredging contracts, of which 84.8 percent were subject to environmental windows. Interestingly, 81.5 percent of dredging projects in the 1974-1979 survey by Profiles Research and Consulting Groups (1980) for their Northeast region (Virginia to Maine) were subject to windows.

Two consistent patterns emerge when evaluating the number of Federal dredging contracts awarded during 1987 through 1996 for each District (based on Pankow 1997). First, the numbers of dredging projects vary greatly among Districts. Second, little interannual variation occurs in the total number of dredging contracts for a given District or the overall USACE dredging program. Assuming that the survey results accurately represent Corps-wide implementation of windows, approximately 117 Federal dredging contracts are affected annually by environmental windows. Atlantic and Pacific Coast Districts reported the highest percentages (84.5 to 100 percent) of projects with restrictions, whereas Districts in the Gulf of Mexico and Mississippi Valley regions reported the

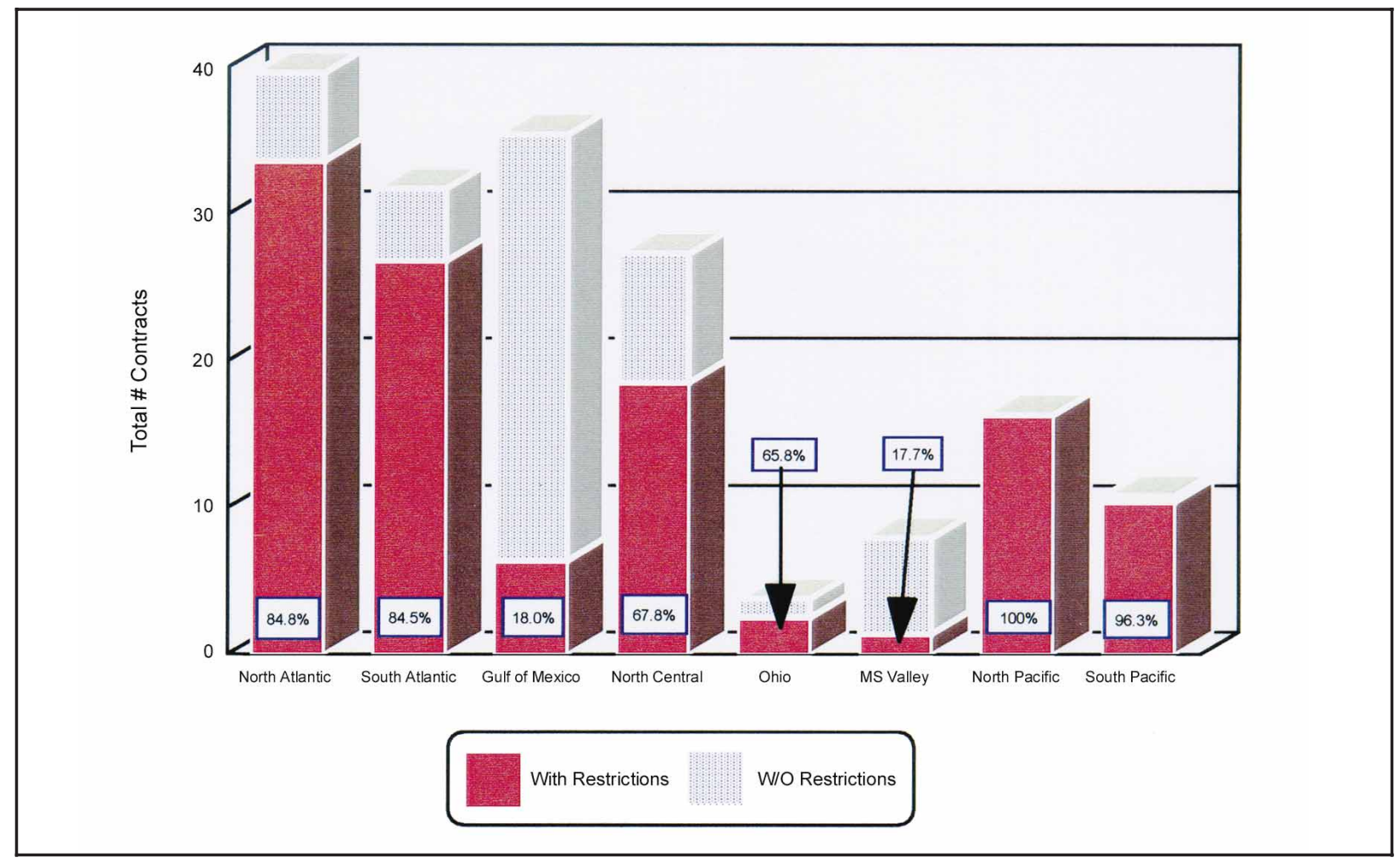

Figure 4. Estimated annual percent occurrence of environmental windows by geographic region (mean number of Federal dredging contracts 1987-1996) 
lowest percentages (approximately 18 percent). Each District was ranked by the number of environmental windows issues reported, as well as the number of annual Federal dredging contracts potentially affected (Table 1). The two ranking factors showed little correspondence. For example, the New England District reported the most environmental windows issues (12), but the Detroit District had a greater number of Federal dredging contracts (mean 15.4) affected annually.

Estimated costs associated with windows. Figure 5 depicts regional variability of average dredging costs per cubic yard (1987-1996) from contracted dredging projects (based on Pankow 1997). It is notable that the geographic regions with the lowest dredging costs per cubic yard also

\begin{tabular}{|c|c|c|c|}
\hline \multicolumn{4}{|c|}{ Ranking of Districts } \\
\hline \multicolumn{2}{|r|}{$\begin{array}{c}\text { By Number of Environmental } \\
\text { Windows Issues }\end{array}$} & \multicolumn{2}{|c|}{$\begin{array}{l}\text { By Estimated Number of Annual Federal } \\
\text { Dredging Contracts with Environmental Windows }\end{array}$} \\
\hline 12 & New England & 15.4 & Detroit \\
\hline 11 & Baltimore & 9.5 & Wilmington \\
\hline 9 & New York & 9.2 & Jacksonville \\
\hline 9 & Philadelphia & 9.1 & Philadelphia \\
\hline 9 & Wilmington & 8.9 & New York \\
\hline 9 & Savannah & 8.8 & Portland \\
\hline 8 & Detroit & 6.5 & San Francisco \\
\hline 8 & St. Louis & 6.4 & Savannah \\
\hline 8 & Sacramento & 6.1 & Norfolk \\
\hline 7 & Norfolk & 5.8 & Baltimore \\
\hline 7 & Charleston & 4.5 & Seattle \\
\hline 7 & Portland & 3.9 & Los Angeles \\
\hline 6 & Omaha & 3.7 & New England \\
\hline 6 & Jacksonville & 3.5 & Mobile \\
\hline 6 & Los Angeles & 3.2 & Rock Island \\
\hline 6 & Alaska & 2.9 & Galveston \\
\hline 5 & Seattle & 2.6 & Alaska \\
\hline 5 & New Orleans & 1.7 & Charleston \\
\hline 5 & San Francisco & 1.6 & Louisville \\
\hline 5 & Mobile & 1.4 & Little Rock \\
\hline 5 & Nashville & 0.7 & Huntington \\
\hline 5 & Louisville & 0.6 & Sacramento \\
\hline 4 & Galveston & 0.4 & St. Paul \\
\hline 4 & Rock Island & 0.4 & Walla Walla \\
\hline 4 & Walla Walla & 0.2 & Chicago \\
\hline 3 & Kansas City & 0.2 & Nashville \\
\hline 2 & Chicago & 0 & Pittsburgh \\
\hline 2 & St. Paul & 0 & Memphis \\
\hline 2 & Memphis & 0 & Kansas City \\
\hline 2 & Honolulu & 0 & Omaha \\
\hline 1 & Huntington & 0 & Honolulu \\
\hline 1 & Pittsburgh & $?$ & New Orleans* \\
\hline 1 & Little Rock & $?$ & St. Louis* \\
\hline
\end{tabular}




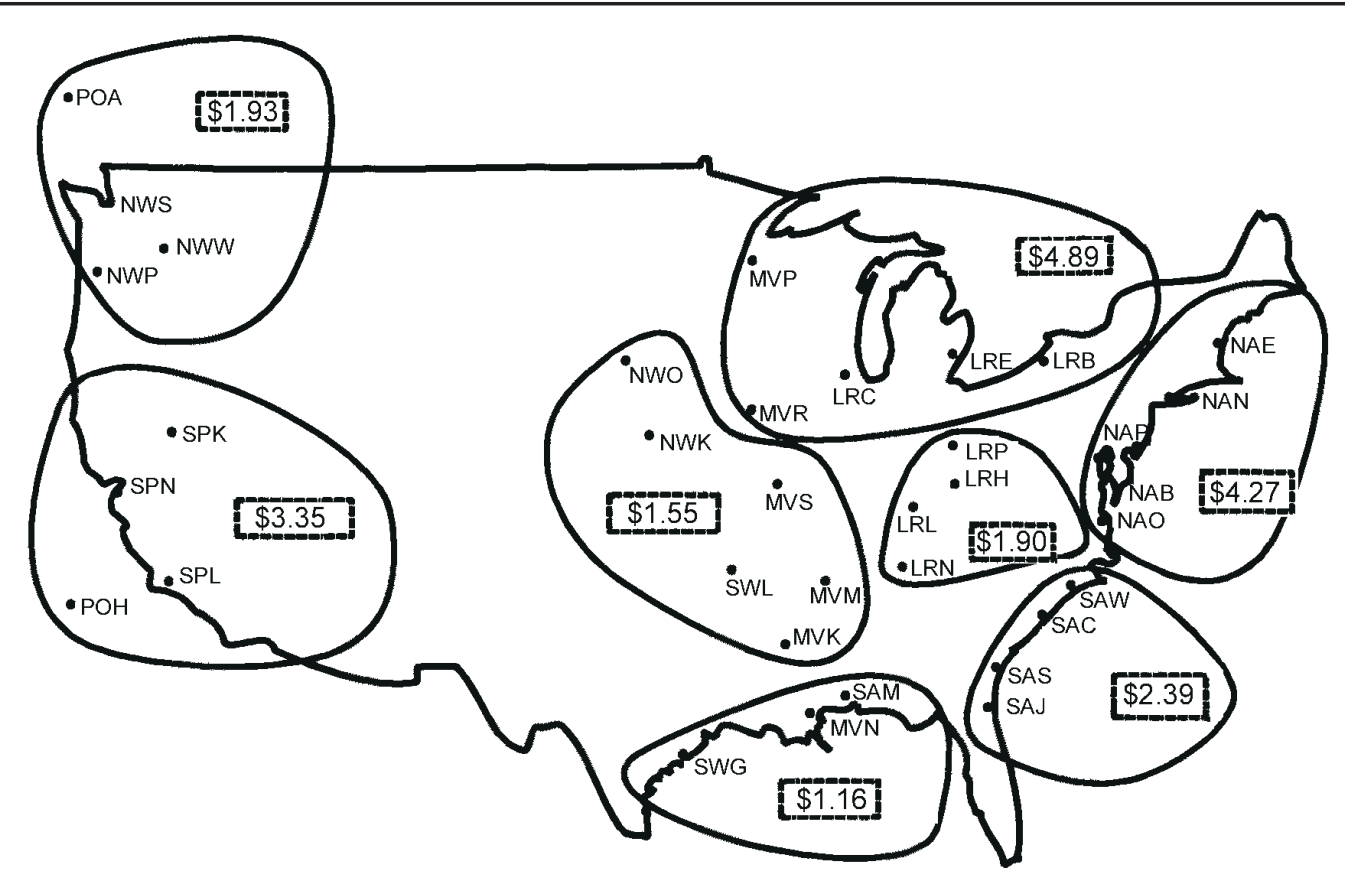

Figure 5. Mean Federal contract dredging costs per cubic yard by geographical region for the period 1986-1997 (based on Pankow 1997)

reported the lowest percentage of projects with environmental windows (Mississippi Valley and Gulf of Mexico regions). Conversely, those regions with the highest dredging costs per cubic yard similarly reported high percentages of projects with restrictions (Atlantic, Pacific, and North Central regions). However, relationships between windows and inflated dredging project costs are not simplistic. Among the many factors considered when calculating dredging project cost estimates are: the type of dredging activity, the total amount of sediment to be removed, whether sediment is removed from continuous or disjunct sections of a channel, method of dredged material disposal, the estimated duration of activity, and the available period of time for dredging. Regional correlations between dredging costs and compliance with environmental windows can also be confounded by scaling factors (moving large volumes of unconsolidated dredged material by hydraulic pipeline can be less expensive on a per cubic yard basis than smaller volumes handled by other dredging modes) and elevated costs of handling contaminated sediments, an important distinction in comparing two regions (e.g., the Gulf of Mexico versus the North Atlantic). The myriad of dredging factors and scenarios throughout the USACE dredging program prevent direct or easy methods for analyzing economic impacts from compliance with environmental windows. Direct comparisons of historical dredging cost information between years, projects, Districts, or dredging regions become impossible because of the uniqueness of each project and inherent inconsistencies in data records and their accessibility. For these reasons, a conservative approach to estimating windows-driven costs was adopted.

The CEDEP is currently used by USACE cost engineers to generate project cost estimates when provided a set of dredging factors (Fletcher and Fore 1996). This cost analysis program was used to calculate cost estimates for the 38 hypothetical dredging scenarios and develop corresponding decision matrices. Figures 6, 7, and 8 provide examples of these matrices for three different 


\begin{tabular}{|l|l|}
\hline \multicolumn{2}{|c|}{ Dredging Scenario A } \\
\hline Dredge Type & CLAMSHELL \\
\hline Number of Dredges & One 16 cubic yard dredge \\
\hline Total Material Volume & $\mathbf{2 5 0 , 0 0 0}$ cubic yards \\
\hline Required & 200,000 \\
\hline Pay Overdepth & 50,000 \\
\hline Material Composition & $\begin{array}{l}\text { Sand only } \\
\text { Mud } \\
\text { Sand } 100 \% \\
\text { Gravel }\end{array}$ \\
\hline Disposal Location & Beach disposal \\
\hline Distance to Dumpsite & 5 miles \\
\hline Dredging Area & $1,350,000$ sq $\mathrm{ft}$ \\
\hline
\end{tabular}

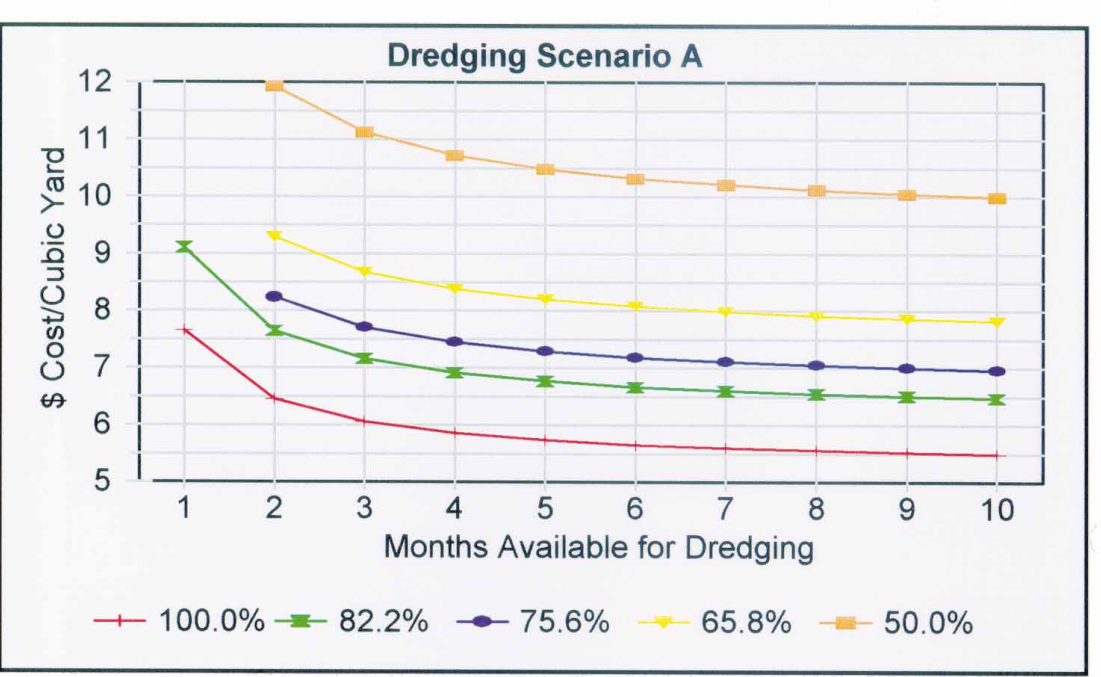

\begin{tabular}{|c|c|c|c|c|c|c|c|c|c|c|c|c|c|}
\hline \multirow[b]{2}{*}{$\begin{array}{l}\text { Dredging } \\
\text { Efficiency }\end{array}$} & \multirow{2}{*}{$\begin{array}{l}\text { Days/Month } \\
\text { Available } \\
\text { to Dredge }\end{array}$} & \multirow{2}{*}{$\begin{array}{l}\text { Months } \\
\text { Required to } \\
\text { Complete } \\
\text { Scenario }\end{array}$} & \multicolumn{11}{|c|}{$\begin{array}{c}\text { Dredging Scenario A } \\
\text { Dredging Cost (\$)/Cubic Yard } \\
\text { By Number of Months Available to Dredge }\end{array}$} \\
\hline & & & 1 & 2 & 3 & 4 & 5 & 6 & 7 & 8 & 9 & 10 & 11 \\
\hline $100.0 \%$ & 30 & 0.82 & 7.66 & 6.46 & 6.06 & 5.86 & 5.74 & 5.66 & 5.60 & 5.56 & 5.53 & 5.50 & 5.48 \\
\hline $82.2 \%$ & 25 & 1.00 & 9.11 & 7.65 & 7.16 & 6.92 & 6.77 & 6.67 & 6.60 & 6.55 & 6.51 & 6.48 & 6.45 \\
\hline $75.6 \%$ & 23 & 1.09 & $x$ & 8.24 & 7.71 & 7.45 & 7.29 & 7.18 & 7.11 & 7.05 & 7.00 & 6.97 & 6.94 \\
\hline $65.8 \%$ & 20 & 1.25 & $x$ & 9.29 & 8.68 & 8.38 & 8.20 & 8.08 & 7.99 & 7.92 & 7.87 & 7.83 & 7.80 \\
\hline $50.0 \%$ & 15 & 1.65 & $x$ & 11.93 & 11.13 & 10.72 & 10.48 & 10.32 & 10.21 & 10.12 & 10.05 & 10.00 & 9.96 \\
\hline
\end{tabular}

Figure 6. Example of an economics matrix for a clamshell dredging scenario 


\begin{tabular}{|c|c|}
\hline \multicolumn{2}{|c|}{ Dredging Scenario B } \\
\hline Dredge Type & HOPPER \\
\hline Number of Dredges & One small dredge \\
\hline Total Material Volume & 250,000 cubic yards \\
\hline Required & 200,000 \\
\hline Pay Overdepth & 50,000 \\
\hline Material Composition & $\begin{array}{lc}\text { Course } & \text { grained } \\
\text { Mud } & 10 \% \\
\text { Sand } & 90 \% \\
\text { Gravel } & 0 \%\end{array}$ \\
\hline Disposal Location & Upland \\
\hline Distance to Dumpsite & 5 miles \\
\hline Dredging Area & $1,350,000 \mathrm{sq} f t$ \\
\hline
\end{tabular}

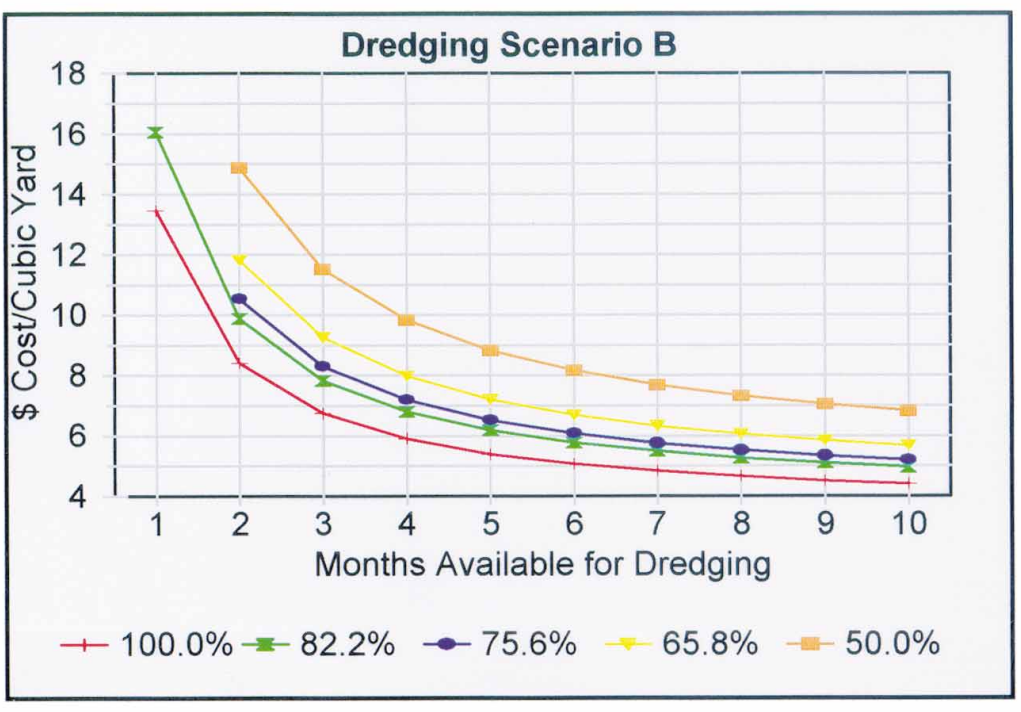

\begin{tabular}{|c|c|c|c|c|c|c|c|c|c|c|c|c|c|}
\hline \multirow[b]{2}{*}{$\begin{array}{l}\text { Dredging } \\
\text { Efficiency }\end{array}$} & \multirow{2}{*}{$\begin{array}{l}\text { Days/Month } \\
\text { Available } \\
\text { to Dredge }\end{array}$} & \multirow{2}{*}{$\begin{array}{l}\text { Months } \\
\text { Required to } \\
\text { Complete } \\
\text { Scenario }\end{array}$} & \multicolumn{11}{|c|}{$\begin{array}{c}\text { Dredging Scenario B } \\
\text { Dredging Cost (\$)/Cubic Yard } \\
\text { By Number of Months Available to Dredge }\end{array}$} \\
\hline & & & 1 & 2 & 3 & 4 & 5 & 6 & 7 & 8 & 9 & 10 & 11 \\
\hline $100.0 \%$ & 30 & 0.80 & 13.47 & 8.43 & 6.75 & 5.92 & 5.41 & 5.08 & 4.84 & 4.66 & 4.52 & 4.41 & 4.31 \\
\hline $82.2 \%$ & 25 & 0.98 & 16.06 & 9.89 & 7.84 & 6.81 & 6.19 & 5.78 & 5.49 & 5.27 & 5.10 & 4.96 & 4.85 \\
\hline $75.6 \%$ & 23 & 1.06 & $x$ & 10.53 & 8.31 & 7.20 & 6.53 & 6.09 & 5.77 & 5.53 & 5.35 & 5.20 & 5.08 \\
\hline $65.8 \%$ & 20 & 1.22 & $x$ & 11.83 & 9.27 & 7.99 & 7.22 & 6.71 & 6.34 & 6.07 & 5.85 & 5.68 & 5.54 \\
\hline $50.0 \%$ & 15 & 1.60 & $x$ & 14.89 & 11.53 & 9.85 & 8.85 & 8.18 & 7.70 & 7.34 & 7.06 & 6.83 & 6.65 \\
\hline
\end{tabular}

Figure 7. Example of an economics matrix for a hopper dredging scenario 


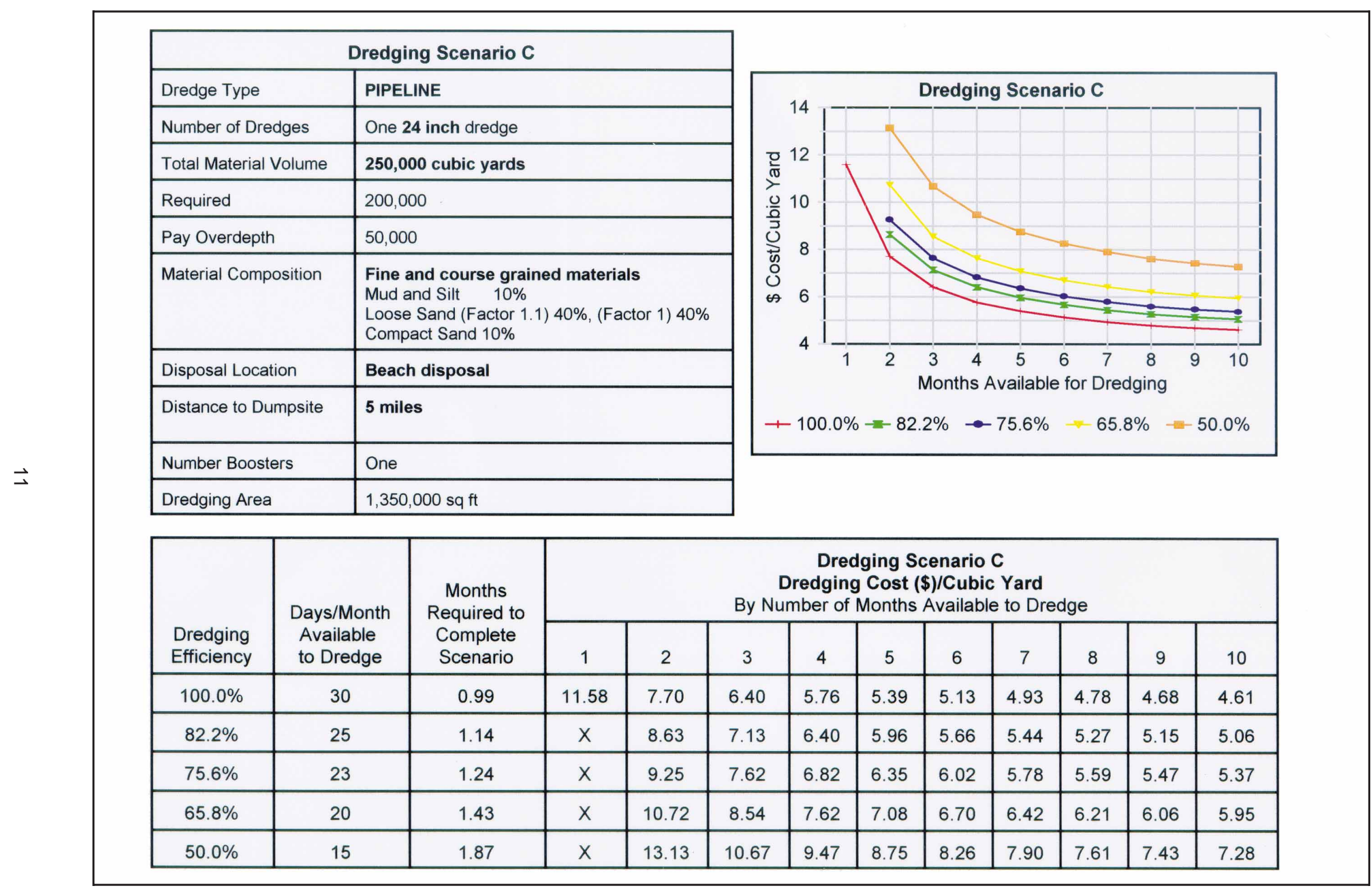

Figure 8. Example of an economics matrix for a pipeline dredging scenario 
dredging methods with similar dredging scenarios. Dredging scenarios included the most commonly used dredge types (pipeline, hopper, and clamshell), exemplifying a range of dredged material compositions and volumes $\left(25,000\right.$ to $\left.>1,000,000 \mathrm{yd}^{3}\right)$, and different disposal methods and placement site distances. Cost estimates per cubic yard were generated for each specified dredging scenario using five different operational efficiencies $(50.0,65.8,75.6,82.2$, and 100 percent, corresponding to $15,20,23,25$, and 30 days per month) and from 1 to 12 months of available time to complete the dredging operation. Dredging efficiency refers to the percent of the total available contract time a dredge is able to operate (e.g., operating $24 \mathrm{hr}$ per day, 7 days per week would equate to 100 percent efficiency). A decision matrix of projected cost estimates (cost per cubic yard) was then created for each of the 38 hypothetical dredging scenarios. North Atlantic regional prevailing wage rates designated by the CEDEP were used for all scenarios except for specific comparisons between regions.

Compliance with environmental windows constrains the number of months available for dredging as well as potentially reduces the overall dredging efficiency of a project. Factors that can contribute to reduced efficiency include: use of a less efficient dredge plant for a given project, increased transport distances to acceptable placement sites, increased fuel costs due to seasonal differences in cost or availability (e.g., during winter when refinery production and storage capacities are shifted to heating fuels) or logistical problems, increased operational time due to reduced vessel speeds, allowances for longer mobilization/demobilization times, increased "down" time for dredge plant maintenance and repair, increased fuel usage during cold weather conditions, precautionary measures to prevent icing hazards, other personnel safety considerations, and personnel availability constraints and equipment delays due to inclement weather. These factors do not represent a comprehensive list, but serve to illustrate the complexity and difficulty in comparing project costs and determining incremental costs associated with environmental windows compliance. Given this caveat, the linkage between temporal constraint of a dredging operation and overall cost appears to be strong. As seen in each of the matrix examples (Figures 6, 7, and 8), dredging costs per cubic yard decrease as both dredging efficiency and months available for dredging increase. Conversely, dredging costs dramatically increase as dredging efficiency and the "window" available for dredging project completion decrease.

Data from the District survey responses and the Contract Dredging Program Database were compiled to provide estimates of numbers of dredging projects conducted and cubic yards of material moved annually under environmental window constraints (Table 2). These are conservative estimates for the overall USACE dredging program considering: (a) the variability in completeness of District survey responses, (b) that only contract dredging data were used, and (c) only median cubic yard values were selected for each dredging category in this table. The dredging scenario matrices can be used to provide estimates of project costs as well as USACE cost savings. These cost matrices indicate that even small modifications in environmental windows can accrue significant cost savings. This is not surprising, given that over 129 million $\mathrm{yd}^{3}$ of dredged material are produced annually by projects subject to windows. Even an overall reduction as small as $\$ 0.01 / \mathrm{yd}^{3}$ would generate a potential annual cost savings of $\$ 1.29$ million.

As stated earlier, a myriad of cost related factors come into play in estimating costs specifically linked to environmental windows. Thus a single cost figure would have little meaning. For example, the cost matrices generated for the selected dredging scenarios clearly show that opening 


\begin{tabular}{|c|c|c|c|c|c|}
\hline $\begin{array}{l}\text { Table } 2 \\
\text { Estimatec } \\
\text { Yardage } \\
\text { USACE D }\end{array}$ & $\begin{array}{l}\text { Annual Number } \\
\text { redged with En } \\
\text { strict Survey Re }\end{array}$ & $\begin{array}{l}\text { Federal D } \\
\text { onmental V } \\
\text { onses) }\end{array}$ & $\begin{array}{l}\text { ging Co } \\
\text { lows (B }\end{array}$ & $\begin{array}{l}\text { cts and } 1 \\
\text { d on Panl }\end{array}$ & $\begin{array}{l}\text { al Cubic } \\
\text { w } 1997 \text { and }\end{array}$ \\
\hline $\begin{array}{l}\text { Dredge } \\
\text { Type }\end{array}$ & $\begin{array}{l}\text { Dredged Material } \\
\text { Volume, } y^{3}\end{array}$ & $\begin{array}{c}\text { Median } \\
\text { Volume, } \mathbf{y d}^{3}\end{array}$ & $\begin{array}{c}\text { Mean } \\
\text { Annual } \\
\text { Contracts }\end{array}$ & $\begin{array}{c}\text { Estimated \# } \\
\text { Contracts } \\
\text { W/Windows }\end{array}$ & $\begin{array}{l}\text { Estimated Total } \\
\text { Dredged } \\
\text { W/Windows, yd }\end{array}$ \\
\hline Pipeline & $<50,000$ & 25,000 & 25.0 & 19.0 & 475,000 \\
\hline & $50,000-99,999$ & 75,000 & 11.0 & 9.2 & 690,000 \\
\hline & $100,000-299,999$ & 200,000 & 17.0 & 12.8 & $2,560,000$ \\
\hline & $300,000-499,999$ & 400,000 & 11.0 & 8.7 & $3,480,000$ \\
\hline & $500,000-999,999$ & 750,000 & 23.0 & 14.3 & $10,725,000$ \\
\hline & $>1,000,000$ & $2,500,000$ & 43.0 & 22.4 & $56,000,000$ \\
\hline & & & 130 & 86.4 & $73,930,000$ \\
\hline Hopper & $<50,000$ & 25,000 & 1.3 & 1.2 & 30,000 \\
\hline & $50,000-99,999$ & 75,000 & 0.8 & 0.7 & 52,500 \\
\hline & $100,000-299,999$ & 200,000 & 5.4 & 4.8 & 960,000 \\
\hline & $300,000-499,999$ & 400,000 & 5.1 & 4.0 & $1,600,000$ \\
\hline & $500,000-999,999$ & 750,000 & 5.9 & 4.7 & $3,525,000$ \\
\hline & $>1,000,000$ & $2,500,000$ & 11.0 & 9.4 & $23,500,000$ \\
\hline & & & 29.5 & 24.8 & $29,667,500$ \\
\hline Bucket & $<50,000$ & 25,000 & 8.4 & 6.7 & 167,500 \\
\hline & $50,000-99,999$ & 75,000 & 6.5 & 5.0 & 375,000 \\
\hline & $100,000-299,999$ & 200,000 & 8.5 & 7.6 & $1,520,000$ \\
\hline & $300,000-499,999$ & 400,000 & 1.8 & 1.7 & 680,000 \\
\hline & $500,000-999,999$ & 750,000 & 3.0 & 2.7 & $2,025,000$ \\
\hline & $>1,000,000$ & $2,500,000$ & 2.6 & 2.5 & $6,250,000$ \\
\hline & & & 30.8 & 26.2 & $11,017,500$ \\
\hline Combination & $<50,000$ & 25,000 & 1.5 & 1.5 & 37,500 \\
\hline & $50,000-99,999$ & 75,000 & 0.7 & 0.5 & 37,500 \\
\hline & $100,000-299,999$ & 200,000 & 1.7 & 1.7 & 340,000 \\
\hline & $300,000-499,999$ & 400,000 & 1.5 & 1.5 & 600,000 \\
\hline & $500,000-999,999$ & 750,000 & 1.8 & 1.8 & $1,350,000$ \\
\hline & $>1,000,000$ & $2,500,000$ & 2.7 & 2.7 & $6,750,000$ \\
\hline & & & 9.9 & 9.7 & $9,115,000$ \\
\hline Other & $<50,000$ & 25,000 & 0.5 & 0.4 & 10,000 \\
\hline & $50,000-99,999$ & 75,000 & 0.1 & 0.1 & 7,500 \\
\hline & $100,000-299,999$ & 200,000 & 0.8 & 0.8 & 160,000 \\
\hline & $300,000-499,999$ & 400,000 & 0.5 & 0.5 & 200,000 \\
\hline & $500,000-999,999$ & 750,000 & 1.1 & 1.1 & 825,000 \\
\hline & $>1,000,000$ & $2,500,000$ & 2.1 & 1.9 & $4,750,000$ \\
\hline & & & 5.1 & 4.8 & $5,952,500$ \\
\hline
\end{tabular}




\begin{tabular}{|c|c|c|c|c|c|c|c|c|c|c|c|c|c|c|c|}
\hline & 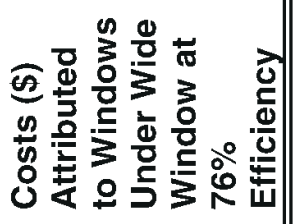 & $\begin{array}{l}\text { 율 } \\
\text { N } \\
\text { లn }\end{array}$ & $\begin{array}{l}8 \\
\stackrel{N}{1} \\
10 \\
10\end{array}$ & $\begin{array}{l}8 \\
8 \\
\text { No } \\
\text { Ln }\end{array}$ & $\begin{array}{l}8 \\
\stackrel{N}{ } \\
\overline{0} \\
\end{array}$ & 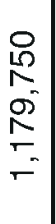 & $\begin{array}{l}8 \\
8 \\
\circ \\
8 \\
0 \\
0 \\
0\end{array}$ & 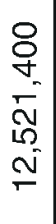 & $\begin{array}{l}8 \\
8 \\
\vdots \\
\text { N }\end{array}$ & $\begin{array}{l}8 \\
8 \\
\text { I }\end{array}$ & 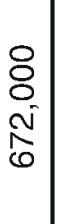 & $\begin{array}{l}8 \\
8 \\
\dot{8} \\
\dot{8}\end{array}$ & $\begin{array}{l}8 \\
0 \\
10 \\
\text { m } \\
8 \\
0 \\
-\end{array}$ & $\begin{array}{l}8 \\
8 \\
0 \\
\\
N \\
\infty \\
\infty\end{array}$ & $\begin{array}{l}8 \\
\frac{8}{-} \\
\dot{+} \\
\infty \\
\frac{-}{\tau}\end{array}$ \\
\hline$\frac{3}{0}$ & 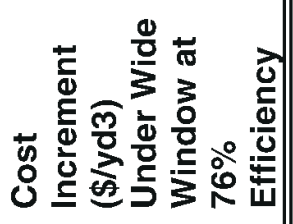 & $\begin{array}{l}\hat{0} \\
0\end{array}$ & $\begin{array}{l}\infty \\
0 \\
0\end{array}$ & ָ̊ & $\frac{\sigma}{\sigma}$ & $\bar{\sigma}$ & $\frac{\infty}{0}$ & & $\begin{array}{l}\tilde{N} \\
\stackrel{0}{\circ}\end{array}$ & $\begin{array}{c}\stackrel{0}{\infty} \\
\dot{0}\end{array}$ & $\begin{array}{l}R \\
0\end{array}$ & $\begin{array}{c}0 \\
0 \\
0 \\
0\end{array}$ & 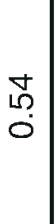 & $\begin{array}{c}\stackrel{0}{m} \\
\dddot{0} \\
0\end{array}$ & \\
\hline 㐫 & 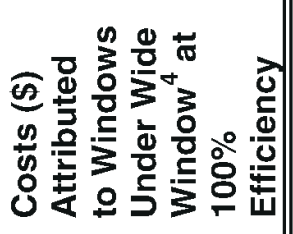 & $\begin{array}{l}\stackrel{\circ}{\circ} \\
\stackrel{\mathcal{D}^{-}}{\mathrm{N}}\end{array}$ & $\begin{array}{l}8 \\
\text { !n } \\
\text { ले }\end{array}$ & 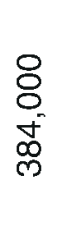 & $\begin{array}{l}8 \\
\stackrel{D}{ } \\
\\
\text { q }\end{array}$ & $\begin{array}{l}8 \\
8 \\
0 \\
\infty \\
10 \\
\infty\end{array}$ & $\begin{array}{l}8 \\
8 \\
0 \\
0 \\
\infty \\
-1\end{array}$ & 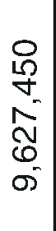 & $\begin{array}{l}8 \\
\stackrel{0}{\circ} \\
\stackrel{-}{-}\end{array}$ & $\begin{array}{l}8 \\
\frac{8}{n} \\
\bar{m}\end{array}$ & $\begin{array}{l}8 \\
8 \\
8 \\
8 \\
\stackrel{\infty}{4}\end{array}$ & $\begin{array}{l}0 \\
8 \\
8 \\
0 \\
0\end{array}$ & 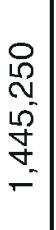 & $\begin{array}{l}8 \\
8 \\
0 \\
10 \\
\infty \\
\infty \\
10\end{array}$ & 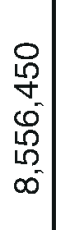 \\
\hline 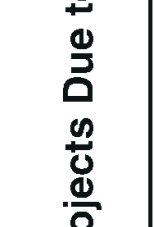 & 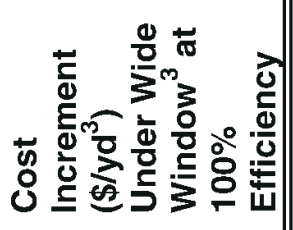 & $\begin{array}{l}\text { L } \\
0 \\
\stackrel{0}{0}\end{array}$ & $\begin{array}{l}\text { L } \\
0 \\
\dot{0}\end{array}$ & $\frac{\omega}{\square}$ & $\frac{\nabla}{\check{0}}$ & $\begin{array}{l}\infty \\
0 \\
0\end{array}$ & $\frac{\pi}{\sigma}$ & & $\begin{array}{l}8 \\
0 \\
0\end{array}$ & $\begin{array}{l}8 \\
\bullet \\
0\end{array}$ & $\begin{array}{c}0 \\
\stackrel{1}{1} \\
0\end{array}$ & $\begin{array}{l}8 \\
\dot{0} \\
0\end{array}$ & $\begin{array}{c}\tilde{\sigma} \\
\dot{0}\end{array}$ & $\begin{array}{l}\stackrel{L}{N} \\
0\end{array}$ & \\
\hline $\begin{array}{l}\frac{2}{0} \\
\frac{0}{c} \\
\frac{5}{0} \\
\frac{d}{2}\end{array}$ & 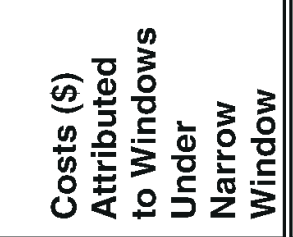 & 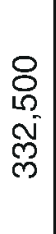 & $\begin{array}{l}8 \\
8 \\
10 \\
0 \\
0 \\
10\end{array}$ & $\begin{array}{l}8 \\
8 \\
8 \\
8 \\
\text { - } \\
\text { n- }\end{array}$ & $\begin{array}{l}8 \\
8 \\
0 \\
0 \\
0 \\
\vdots \\
0\end{array}$ & \begin{tabular}{l}
0 \\
$\stackrel{1}{1}$ \\
$N$ \\
\\
m \\
\multirow{j}{*}{}
\end{tabular} & $\begin{array}{l}8 \\
8 \\
8 \\
0 \\
0 \\
= \\
=\end{array}$ & 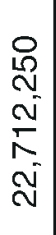 & $\begin{array}{l}8 \\
8 \\
N \\
\frac{N}{m}\end{array}$ & 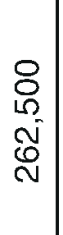 & $\begin{array}{l}8 \\
8 \\
0 \\
8 \\
m \\
m \\
n\end{array}$ & $\begin{array}{l}8 \\
8 \\
0 \\
0 \\
10 \\
\infty\end{array}$ & $\begin{array}{l}8 \\
8 \\
10 \\
10 \\
\circ \\
10 \\
0\end{array}$ & 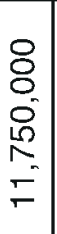 & $\begin{array}{l}8 \\
8 \\
\infty \\
\infty \\
\infty \\
\text { Ñ }\end{array}$ \\
\hline 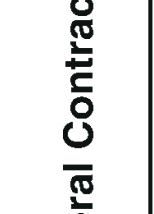 & 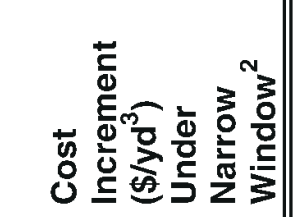 & $\begin{array}{l}P \\
0 \\
0\end{array}$ & $\begin{array}{l}10 \\
\infty \\
0 \\
0\end{array}$ & $\stackrel{\mathscr{L}}{\stackrel{\Gamma}{\Gamma}}$ & $\begin{array}{l}R \\
0 \\
0\end{array}$ & $\begin{array}{l}\tau \\
\dot{0} \\
0\end{array}$ & $\begin{array}{l}\bar{N} \\
0 \\
0\end{array}$ & & 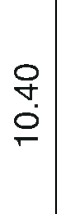 & $\begin{array}{c}8 \\
8 \\
i\end{array}$ & $\begin{array}{l}\text { 号 } \\
\text { लె }\end{array}$ & $\begin{array}{l}\stackrel{M}{N} \\
\text { N }\end{array}$ & 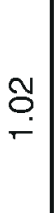 & $\begin{array}{c}0 \\
10 \\
0\end{array}$ & \\
\hline \begin{tabular}{l}
0 \\
\multirow{1}{0}{} \\
0 \\
0 \\
0 \\
0 \\
0 \\
0
\end{tabular} & 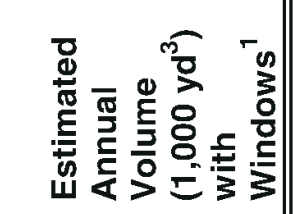 & $\begin{array}{l}0 \\
10 \\
\stackrel{1}{\circ} \\
\text { f }\end{array}$ & $\begin{array}{l}\circ \\
\stackrel{8}{8} \\
8\end{array}$ & $\begin{array}{l}0 \\
8 \\
0 \\
10 \\
N\end{array}$ & $\begin{array}{l}0 \\
\check{0} \\
\infty \\
\dot{y} \\
m\end{array}$ & $\begin{array}{l}0 \\
\text { ํํ } \\
\text { N } \\
0 \\
0\end{array}$ & $\begin{array}{l}\circ \\
\stackrel{8}{8} \\
8 \\
0 \\
0 \\
10\end{array}$ & $\begin{array}{l}\circ \\
0 \\
\bar{m} \\
0 \\
p^{\prime}\end{array}$ & $\begin{array}{l}\circ \\
\text { ஜ }\end{array}$ & $\begin{array}{l}\text { مी } \\
\text { Nิ }\end{array}$ & $\begin{array}{l}0 \\
\dot{8} \\
\ddot{8}\end{array}$ & $\begin{array}{l}0 \\
8 \\
8 \\
0 \\
-\end{array}$ & 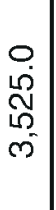 & $\begin{array}{l}\stackrel{0}{0} \\
\stackrel{8}{0} \\
\stackrel{1}{1} \\
\text { N }\end{array}$ & 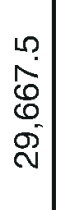 \\
\hline 을 & 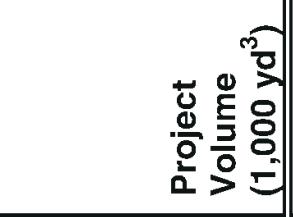 & 욤 & $\frac{8}{\frac{1}{1}}$ & $\begin{array}{l}8 \\
0 \\
1 \\
1 \\
\end{array}$ & $\begin{array}{l}8 \\
0 \\
1 \\
1 \\
\\
0\end{array}$ & $\begin{array}{l}8 \\
8 \\
\frac{1}{1} \\
\frac{1}{0} \\
10\end{array}$ & $\begin{array}{l}8 \\
8 \\
\frac{8}{\wedge}\end{array}$ & $\begin{array}{l}\text { कू } \\
\frac{0}{0} \\
\text { 을 } \\
\text { ज }\end{array}$ & $\stackrel{\circ}{\circ}$ & $\frac{8}{\frac{1}{1}}$ & $\begin{array}{l}8 \\
0 \\
1 \\
\frac{1}{0}\end{array}$ & $\begin{array}{l}8 \\
8 \\
1 \\
1 \\
0 \\
0\end{array}$ & $\begin{array}{l}8 \\
8 \\
\frac{0}{1} \\
\dot{0} \\
\end{array}$ & $\begin{array}{l}8 \\
8 \\
\frac{8}{\wedge}\end{array}$ & $\begin{array}{l}\bar{\pi} \\
\frac{0}{0} \\
\frac{0}{3} \\
\dot{\omega}\end{array}$ \\
\hline 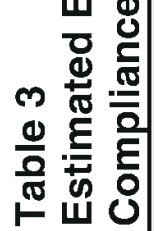 & 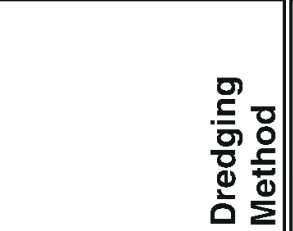 & $\begin{array}{l}\frac{\mathscr{\Xi}}{\bar{\Xi}} \\
\frac{.0}{\alpha} \\
\end{array}$ & & & & & & & $\begin{array}{l}\bar{\Phi} \\
\frac{0}{0} \\
\text { 옹 }\end{array}$ & & & & & & \\
\hline
\end{tabular}




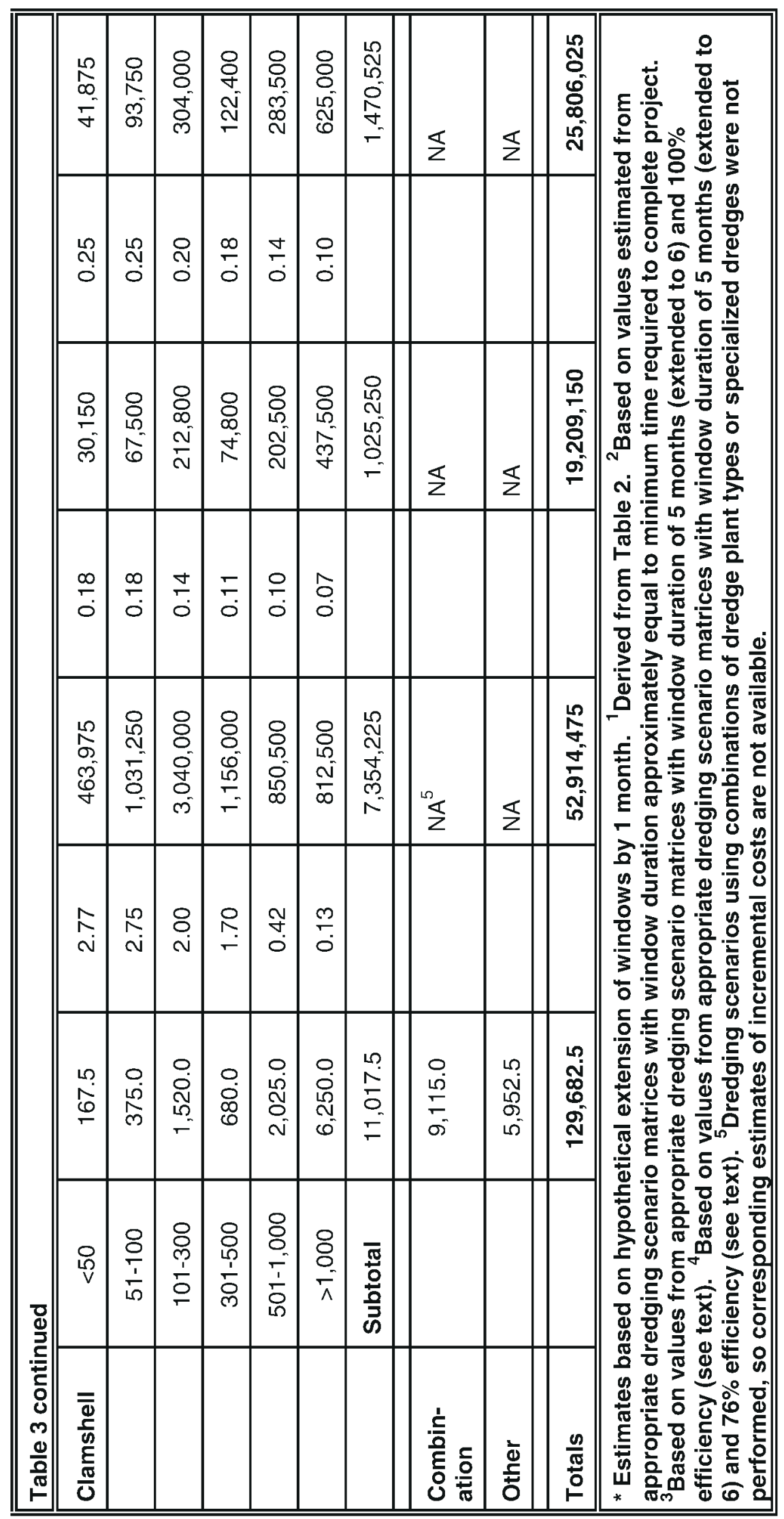


a window that closely approximates the minimum time required to complete a project produces a larger cost reduction than opening a window that is theoretically broad enough to accommodate a window (but remains problematic due to specific start or end dates). To examine these different circumstances, several cost estimates were calculated as presented in Table 3. Costs were estimated for dredging projects categorized in terms of dredge plant and dredged material volume. The latter values were taken from Table 2. First, costs were estimated assuming that very restrictive (i.e., the existing window was approximately equal to the minimum time necessary to dredge under ideal conditions) windows were lengthened by one month. These windows generated the largest incremental costs per cubic yard, but represent an unknown fraction of all projects subject to windows. To examine less restrictive windows, incremental costs were estimated from the dredging scenario matrices for windows of 5-month durations, extended to 6 months, with the assumption of 100 percent dredge efficiency (dredge operating continuously). This method produced very conservative estimates (Table 3). A more realistic dredge efficiency of 76 percent was used to calculate the final cost estimates (Table 3 ).

Table 3 presents estimated incremental costs attributable to compliance with environmental windows, given numerous assumptions as described previously. Likewise, these estimates represent potential cost savings if resolution of technical issues underlying the need for windows led to wider, more flexible windows. It should be recognized that table values represent upper limits of incremental costs or potential savings. Because windows are not likely to be eliminated across broad categories of dredging operations, and indeed in certain situations may ultimately need to be tightened to provide adequate resource protection, accruable cost savings will undoubtedly be some fraction of the totals presented in Table 3. Nevertheless, even small fractions of these conservative estimates, when viewed as annual savings, are significant. Focusing on the most conservative estimates (i.e., for expanding wide windows with 100 percent dredge efficiency), potential cost savings exceed \$19 million on an annual basis (Table 3).

Another conclusion that can be drawn from Table 3 is that potential cost savings are relatively equally distributed among pipeline, hopper, and clamshell dredging projects. The greater volumes handled by pipeline operations are offset somewhat by higher cost factors associated with hopper and clamshell operations.

SUMMARY: The results of these analyses, although based on numerous assumptions, indicate that substantial cost increments arise in connection with environmental windows, and that substantial cost savings could be derived from resolution of over-restrictive windows. These findings justify new investigations or re-examination of technical issues underlying requests for windows and deserve serious consideration. For all dredging operations, concerted efforts must be maintained to adequately protect valuable natural resources. Many areas of potential research, however, afford an opportunity to remove subjectivity from requests for environmental windows. Rigorous, technically valid studies on environmental windows are needed to evaluate fundamental issues such that windows can be confidently adjusted, either through contraction or expansion, to strike the necessary balance between adequate resource protection and cost effective dredging practices. Those technical issues include: (a) effects of physical disturbance on spawning, feeding, or nesting habitats for certain species, (b) sedimentation effects on various biological resources, (c) effects of elevated suspended sediment concentrations on fish survival, (d) hydraulic entrainment of aquatic 
organisms by pipeline and hopper dredges, and (e) potential blockage of pathways for various migrating fishes by turbidity plumes.

Research efforts to address each of these areas should be aggressively pursued in coordination and collaboration with appropriate resource agencies. A tendency to be conservative in light of uncertainty regarding potential detrimental impacts of dredging operations while executing their mandate (i.e., protection of biological resources) is justified and to be expected. Progress toward a basic understanding of the real need for windows can only be achieved by reducing the degrees of uncertainty surrounding impacts and the means to avoid them. A multidisciplinary working group (researchers, dredging industry experts, and District and resource agency personnel) is needed to integrate prioritized research areas with field opportunities of ongoing dredging projects. Partnering efforts between Districts with similar problematic windows-related issues should be considered whenever possible. As new information is obtained, the validity of individual, or categories of, restrictions should be reevaluated.

This examination of economic effects of compliance with environmental windows should not be construed to be an argument in itself against the utility or effectiveness of windows. Clearly, in many dredging scenarios, windows are sensible means of achieving resource protection. However, if progress is to be made toward resolution of windows based on insufficient, subjective, or anecdotal data, or on questionable technical rationales, then, the most problematic issues must first be identified. Also, the economic effects on dredging operations described herein are not purported to be based on comprehensive economic analyses. No attempt has been made, for example, to estimate the monetary value of any biological resource "lost" as a consequence of a given dredging scenario. Such an analysis is beyond the scope of this work.

ACKNOWLEDGEMENTS: The survey responses and information received from the USACE Districts and the Institute for Water Resources throughout this study were essential ingredients of the data analyses presented. The expertise, time, and effort given by the numerous survey respondents were an invaluable contribution to this effort. We also wish to express our appreciation to Ms. Virginia Pankow and Mr. Bill Hansen of the Institute for Water Resources for their advice on approaches to dredging project cost estimation and access to useful databases. Mr. Joe Wilson (USACE Headquarters) and Mr. Bob Blama (USACE District, Baltimore) were instrumental in the initial planning phases of this work and coordination of data collection. Mr. Oliver Leimbach (USACE District, Baltimore) was the lead dredging cost engineer assisting in the cost analyses presented. Ms. Kim Herrmann (USACE Waterways Experiment Station (WES)) provided valuable assistance in tabulation and graphical presentation of the dredging data.

POINTS OF CONTACT: For additional information, contact one of the authors-Ms. Dena D. Dickerson (601-634-3772, dickerd@mail.wes.army.mil), Mr. Kevin J. Reine (601-634-3436, reinek@mail.wes.army.mil), or Dr. Douglas G. Clarke (601-634-3770, clarked@mail. wes.army.mil) of the Coastal Ecology Branch, Environmental Resources Division, Environmental Laboratory, WES, or the managers of the Dredging Operations and Environmental Research Program, Mr. E. Clark McNair (601-634-2070, mcnairc@mail.wes.army.mil) and Dr. Robert M. Engler (601-634-3624, englerr@mail.wes.army.mil). This technical note should be cited as follows: 
Dickerson, D. D., Reine, K. J., and Clarke, D. G. (1998). "Economic impacts of environmental windows associated with dredging operations," DOER Technical Notes Collection (TN DOER-E3), U.S. Army Engineer Research and Development Center, Vicksburg, MS. www.wes.army.mil/el/dots/doer

\section{REFERENCES}

Boerger, F., and Cheney, M. (1976). "Economic impact of dredging regulations," Proceedings of the specialty conference on dredging and its environmental effects. P. Krenkel, J. Harrison, and J. Burdick, ed., American Society of Civil Engineers, New York, 408-17.

Cable, C., and Pearson, W. (1976). "Environmental costs - Impact on dredging," Proceedings of the specialty conference on dredging and its environmental effects. P. Krenkel, J. Harrison, and J. Burdick, ed., American Society of Civil Engineers, New York, 353-63.

Fletcher, A., and Fore, A. (1996). "Headquarters, USACE Cost Engineering Dredge Estimating Program (CEDEP)," Draft version. Software developed by U.S. Army Corps of Engineers Jacksonville District.

LaSalle, M., Clarke, D., Homziak, J., Lunz, J., and Fredette, T. (1991). "A framework for assessing the need for seasonal restrictions on dredging and disposal operations," Technical Report D-91-1, U.S. Army Engineer Waterways Experiment Station, Vicksburg, MS.

Pankow, V. (1997). "USACE contract dredging program database," Computer database maintained by the U.S. Army Corps of Engineers Institute for Water Resources, Alexandria, VA.

Pointon, M. (1996). "Dredging costs analysis information paper," Internet website (http://www.wrc-ndc. usace.army.mil) sponsored by the U.S. Army Corps of Engineers Institute for Water Resources, Alexandria, VA.

Profiles Research and Consulting Groups (1980). "Seasonal restrictions on dredging projects by NMFS in the northeast," Contract Report for the Environmental Assessment Branch, U.S. Department of Commerce, National Marine Fisheries Service, 2 Volumes.

Reine, K., Dickerson, D., and Clarke, D. (1998). “Environmental windows associated with dredging operations," DOER Technical Note Collection (TN DOER-E2), U.S. Army Engineer Research and Development Center, Vicksburg, MS. www.wes.army.mil/el/dots/doer

Sanders, L., and Killgore, J. (1989). "Seasonal restrictions on dredging operations in freshwater systems," Environmental Effects of Dredging Technical Note EEDP-01-16, U.S. Army Engineer Waterways Experiment Station, Vicksburg, MS. 